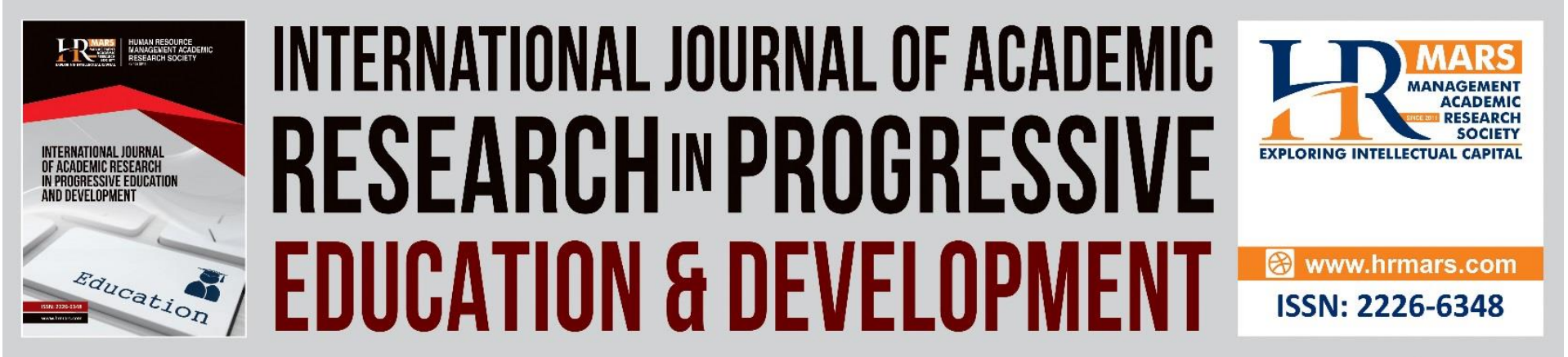

\title{
Teachers' Perceptions in Using Online Applications to Teach Vocabulary During Online Learning
}

Siti Noor Haslina Md Latip, Ilidina Mahadi

To Link this Article: http://dx.doi.org/10.6007/IJARPED/v10-i4/11843

DOI:10.6007/IJARPED/v10-i4/11843

Received: 04 September 2021, Revised: 06 October 2021, Accepted: 25 October 2021

Published Online: 14 November 2021

In-Text Citation: (Latip \& Mahadi, 2021)

To Cite this Article: Latip, S. N. H. M., \& Mahadi, I. (2021). Teachers' Perceptions in Using Online Applications to Teach Vocabulary During Online Learning. International Journal of Academic Research in Progressive Education and Development, 10(4), 72-83.

Copyright: (C) 2021 The Author(s)

Published by Human Resource Management Academic Research Society (www.hrmars.com)

This article is published under the Creative Commons Attribution (CC BY 4.0) license. Anyone may reproduce, distribute, translate and create derivative works of this article (for both commercial and non-commercial purposes), subject to full attribution to the original publication and authors. The full terms of this license may be seen

at: http://creativecommons.org/licences/by/4.0/legalcode

Vol. 10(4) 2021, Pg. 72 - 83

http://hrmars.com/index.php/pages/detail/IJARPED

JOURNAL HOMEPAGE

Full Terms \& Conditions of access and use can be found at http://hrmars.com/index.php/pages/detail/publication-ethics 


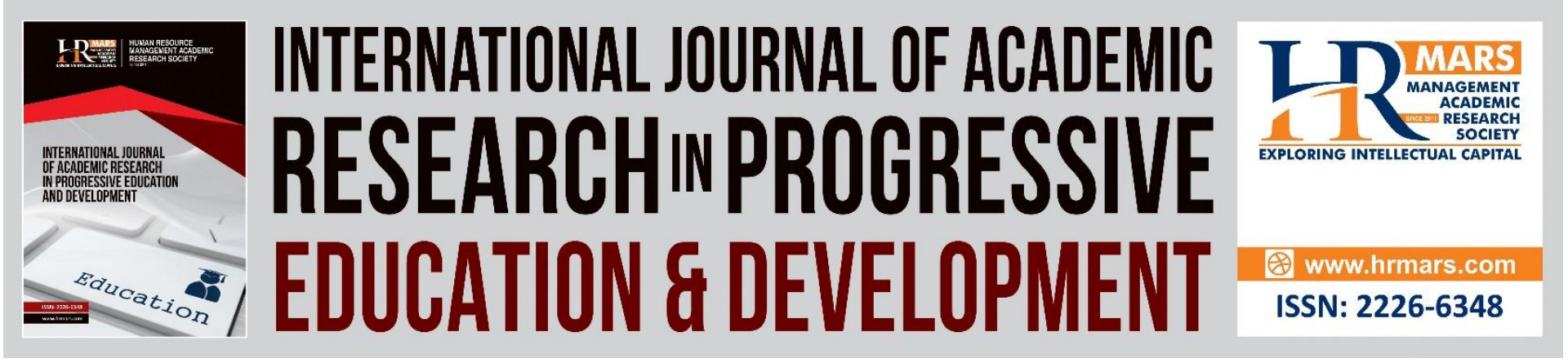

\title{
Teachers' Perceptions in Using Online Applications to Teach Vocabulary During Online Learning
}

\author{
Siti Noor Haslina Md Latip \\ Faculty of Educational Studies, Universiti Putra Malaysia Selangor, Malaysia
}

Ilidina Mahadi

Kuliyyah of Education, International Islamic University Malaysia (IIUM) Selangor, Malaysia

\begin{abstract}
Covid-19 pandemic has made a total shift in education, from face-to-face learning to fully online learning in most of the countries. This study investigates English teachers' perceptions in using online applications to teach vocabulary at the secondary school level. This study involved English secondary school teachers in one of the districts in Terengganu. This study used the quantitative method through the survey approach. This research used SPSS version 26 in analysing through descriptive analysis to identify mean and standard deviation. The findings revealed that there are mixed perceptions among the teachers in using online applications to teach vocabulary. WhatsApp and Telegram are the two frequently used online applications in teaching vocabulary by teachers. Even though the unplanned and rapid move to online learning gives impact on teachers and students, teachers were still optimistic about teaching vocabulary using online applications. This research is hoped to give impact to the school administration, educational policymakers in integrating the nature of the online application to the teaching-learning process.
\end{abstract}

Keywords: Covid-19, Online, Online Learning, Online Applications, Vocabulary, Secondary School

\section{Introduction}

The Coronavirus 19 (Covid-19) has given such an extensive effect on global education. To flatten the curve of Covid-19, Movement Control Order (MCO) has been enforced in most countries. The MCO has interrupted learning for learners up to seven million institutions from preschool to tertiary level (UNESCO, 2020). In Malaysia, the Ministry of Education has announced that teaching and learning should be continued via online learning as face-to-face or conventional teaching and learning is not the best option during this pandemic. This rapid move to online learning due to Covid-19 has witnessed a worldwide field of education in a different perspective. Technology connects us all. However, an unexpected and sudden move to technology - the teaching of online learning with not much training, insufficient internet connection, and little preparation will result in a poor experience in learning activities 
(Purwanto et al., 2020). Teachers are finding solutions to make sure the gaps are filled, and students could still benefit from their online learning.

In the Malaysia Education Blueprint 2013-2025, Shift 7 highlights that MOE aims to leverage the use of ICT in elevating quality learning across Malaysia. The aim is for "the students to be able to access a wider range of content that is more engaging and interactive" (Malaysia Education Blueprint, 2013-2025). The Industrial Revolution 4.0 (IR4.0) has given some new propulsion towards our education. Education 4.0 is indeed geared towards innovations, and students need to produce new inventions. IR4.0 demands changes in the contents of not only technical education but also education in general. Thus, the looming technologies monopolize the digital world, of which education is one of the crucial keys (Anderson, 2017)

Various studies have shown the positive impact of learning with mobile technology, which can increase students' engagement and enhance motivation in learning when students learn from various perspectives (Botickí et al., 2015; Yang et al., 2015). With the restriction of $\mathrm{MCO}$, online learning appears to be inevitable for teachers and students, and online learning is currently the mainstream education (Coates et al., 2020). Online learning is seen as a subcategory of distance education using the internet (Bates, 2005). It requires communication and active interaction on digital devices. There are many online teaching methods available, for instance, Google Classroom, Telegram, Google Meet, Zoom, Padlet, and others. Increasing engagement in learning and fostering autonomous learning facilitates access to information and promotes collaborative learning. Online education applications range from social networks to gamified applications, which have proven a positive correlation among students' achievement and attitude in using applications compared to computer-based instruction (Martin \& Ertzberger, 2013, as cited in Donigo \& Garganté, 2016). Computer-assisted language learning (CALL) and Mobile assisted language learning (MALL) are a reflection of technology integration in the teaching process (Hashim et al., 2017). Educational applications, which are commonly applied in CALL or MALL, are an effective tool to be used in the digital classroom, enabling students to facilitate active language learning.

Teaching English using technology is not a new concept for teachers around the globe. The use of CALL and MALL is typically associated with positive effects on mastering a second language (L2) in comparison to both no treatment and conventional methods (Chen et al., 2018). Learning vocabulary is an essential part of $L 2$ as the foundation in enhancing listening, reading, speaking, and writing (Gorjian et al., 2011). The importance of vocabulary in L2 learning is not limited to in-class time; therefore, it is relatable to see how technology, educational applications assist in vocabulary learning incidentally (Baris et al., 2016; Franciosi, 2017; Taj et al., 2017; as cited in Hao et al., 2021).

Therefore, this study is intended to investigate teachers' perceptions of using online applications to teach vocabulary. Initially, this study also explored types of preferable educational applications to teach vocabulary. Specifically, the objectives of the study are as follows:

1) to investigate the educational online applications English teachers use to teach vocabulary in online learning.

2) to investigate the perceptions of English teachers in using educational online applications in teaching vocabulary. 


\section{Literature Review}

The rapid growth of Information and Communication Technology (ICT) has given the opportunity of using technology in teaching and learning (Willis et al., 2019). Teaching and learning of vocabulary using online applications have been pervasive. A mixed-method study done by Alfehaid (2019) investigating the impact of online learning activities using the online application the Writing Tutor among university students has found that $85 \%$ of students recommended online activities to other students, $97 \%$ of teachers recommended online practice activities to other teachers and believed that online learning activities using applications are beneficial for their students' learning. The most frequent components used were the practice activities, followed by vocabulary skills activities. From the study, it reflects that online learning has a significant impact on teachers and students, which engages teachers and students in exploring knowledge.

Another similar study by Famularsih (2020) on students' experiences using online learning applications due to Covid-19 in Indonesia found that $84 \%$ of respondents agreed that learning materials provided by them in online learning helped students in improving their understanding of the subject and were able to assist them in practicing their English skills. $64 \%$ of respondents agreed that online learning saves their effort and time in learning activities. Students give positive responses to online learning in terms of materials relevancy, convenience, and motivation to learn English. WhatsApp group is among students' preferable online interaction with their educators.

There are many other recent studies that have proven that teaching vocabulary using applications helped to sustain students' focus (Anreadni \& Ying, 2019; Lin, 2015), provides healthy competition among students (Lakshmi, 2016), and a recent study by Wong and Yunus (2020) found that students could also learn vocabulary posted by their peers on the online application, Mentimeter. Thus, vocabulary could be acquired in a fun way through students' learning preferences (Godwin-Jones, 2014; as cited in Huei et al., 2021).

On the contrary, there are few studies reported on the disadvantages and challenges in using applications to teach vocabulary. One of the biggest challenges is that due to time constraints, learning objectives could not be achieved based on allocated time (Earslan \& Topkaya, 2017). Unstable internet connection, lack of support, not enough knowledge, and incompetent in using technology are among other challenges found (Adnyani et al., 2020; Ningsih \& Mulyono, 2019). Several senior teachers mentioned it is difficult to integrate new technology into their teaching due to a lack of training (Nguyen \& Yukawa, 2019; Ningsih \& Mulyono, 2019; Cetin, 2018).

\section{Methodology}

For this study, quantitative research with a survey design was used to collect and analyse the data obtained from the respondents. An online questionnaire was adapted and edited from Rezaei, Mai, and Pesaranghader (2013); Ghavifekr et al (2016) to address the two research objectives for this study.

An online questionnaire consisting of two sections and 17 items was sent to the respondents through a link to a Google form. The questionnaire was based on a 5-point Likert 
Scale ranging from: 5 = strongly agree, $4=$ agree, $3=$ not sure, $2=$ disagree and $1=$ strongly disagree.

A total of 67 English secondary school teachers in a district in Terengganu state were selected purposely as the sample for the study. Purposive sampling was used for this study. Based on Kumar (2019), this type of sampling is where the researchers go to people with the required information and are willing to share it. The sample responded to the statements given and chose their answers based on their perceptions. The two sections of the questionnaire included: (A) Respondents demographic, (B) Teachers perceptions on ICT in teaching and using online applications in teaching vocabulary.

\section{Reliability of the Questionnaire}

\section{Table 1: Cronbach's Alpha Reliability of the Questionnaire}

\begin{tabular}{l|l}
$\begin{array}{l}\text { Cronbach's } \\
\text { AlphA }\end{array}$ & N of Items \\
\hline .908 & 12 \\
\hline
\end{tabular}

Note: .80 to 1.0 as high reliability and below .6 as low reliability

The questionnaire used in this study is reliable and found to be consistent ( $\alpha=.908$ )

\section{Findings}

Demographic background of the respondents

The following Table 1 shows the demographic background of the research participants. 
Table 1. Demographic Findings on Sample

\begin{tabular}{|c|c|c|c|}
\hline Factors & Categories & Frequency & Percentage (\%) \\
\hline \multirow[t]{4}{*}{ Age } & $20-30$ years old & 7 & 10.4 \\
\hline & $31-40$ years old & 35 & 52.2 \\
\hline & $41-50$ years old & 16 & 23.9 \\
\hline & $51-60$ years old & 9 & 13.4 \\
\hline \multirow[t]{2}{*}{ Gender } & Male & 5 & 7.5 \\
\hline & Female & 62 & 92.5 \\
\hline \multirow[t]{2}{*}{ Teaching English as } & Option & 56 & 83.6 \\
\hline & Non-option & 11 & 16.4 \\
\hline \multirow{6}{*}{$\begin{array}{l}\text { Number of Years } \\
\text { Teaching English }\end{array}$} & Less than a year & 3 & 4.5 \\
\hline & $1-5$ years & 10 & 14.9 \\
\hline & $6-10$ years & 27 & 40.3 \\
\hline & $11-15$ years & 7 & 10.4 \\
\hline & $16-20$ years & 7 & 10.4 \\
\hline & More than 20 years & 13 & 19.4 \\
\hline
\end{tabular}

Table 1 demonstrates the demographic finding where the age category 20-30 years old is frequency 7 and percentage is $10.4 \%$, age $31-40$ years old is frequency 35 and percentage is $52.2 \%$, age $41-50$ years old is frequency 16 and percentage is $23.9 \%$, and age 51-60 years old is frequency 9 and percentage is $13.4 \%$. The gender finding shows male as frequency 5 and percentage is $7.5 \%$ and female is frequency 62 and percentage is $92.5 \%$.

Next, is the findings of teaching English as it shows that the number of option teachers are 56 and percentage is $83.6 \%$ and there are 11 non-option teachers and percentage is $16.4 \%$. The findings for number of years teaching English based on the sample is less than 1 
year frequency is 3 and the percentage is $4.5 \%, 1-5$ years frequency is 10 and the percentage is $14.9 \%, 6-10$ years frequency is 27 and the percentage is $40.3 \%, 11-15$ years frequency is 7 and the percentage is $10.4 \%, 16-20$ years frequency is 7 and percentage is $10.4 \%$, and more than 20 years frequency is 13 and the percentage is $19.4 \%$.

\section{Research Questions}

1) What are the educational online applications English teachers use to teach vocabulary in online learning?

The following Table 2 shows the descriptive statistics of teachers' frequent online application in teaching vocabulary during online learning. For this part of the questionnaire, teachers are allowed to choose more than one online application.

Table 2. Frequent Online Application Use to Teach Vocabulary During Online Learning

Online Applications Frequency Percentage (\%)

\begin{tabular}{l|ll}
\hline Google Classroom & 22 & 32.8 \\
Google Form & 32 & 47.8 \\
Google Meet & 1 & 1.5 \\
Padlet & 12 & 17.9 \\
Kahoot & 10 & 14.9 \\
Quizziz & 34 & 50.7 \\
Whatsapp & 53 & 79.1 \\
Telegram & 45 & 67.2 \\
Liveworksheet.com & 5 & 7.5 \\
Youtube & 2 & 3 \\
Wordwall & 2 & 3.5 \\
Quizwhizzer & 2 & 3 \\
\hline
\end{tabular}


Based on Table 2, the majority of teachers chose Whatsapp as their go-to online application when teaching vocabulary during online learning. Followed by Telegram with 45 teachers and Quizziz with a percentage of $50.7 \%$ out of the teachers. The least online applications used by the teachers are Quizwhizzer and Google Meet with only 1 teacher having chosen both.

2) What are the English teachers' perceptions in using educational online applications in teaching vocabulary?

The following table 3 shows the perceptions of teachers in using educational online applications in teaching vocabulary.

Table 3. Use of Educational Online applications in Teaching Vocabulary

\begin{tabular}{|c|c|c|c|c|c|c|c|}
\hline Items & $\begin{array}{l}\text { Strongly } \\
\text { Disagre } \\
\text { e }\end{array}$ & $\begin{array}{l}\text { Disagre } \\
\text { e }\end{array}$ & $\begin{array}{l}\text { Not } \\
\text { Sure }\end{array}$ & Agree & $\begin{array}{l}\text { Strongl } \\
\text { y Agree }\end{array}$ & Mean & SD \\
\hline $\begin{array}{l}\text { 1.ICT facilitates } \\
\text { collaborative work } \\
\text { between students }\end{array}$ & 0 & $\begin{array}{l}3 \\
(4.5 \%)\end{array}$ & $\begin{array}{l}23 \\
(34.3 \%)\end{array}$ & $\begin{array}{l}30 \\
(44.8 \%)\end{array}$ & $\begin{array}{l}11 \\
(16.4 \%)\end{array}$ & 3.73 & .78 \\
\hline $\begin{array}{l}2 . I C T \text { improves the } \\
\text { online learning (pdpr) } \\
\text { (students } \\
\text { engaged, more } \\
\text { disturbing) }\end{array}$ & 0 & $\begin{array}{l}14 \\
(20.9 \%)\end{array}$ & $\begin{array}{l}24 \\
(35.8 \%)\end{array}$ & $\begin{array}{l}24 \\
(35.8 \%)\end{array}$ & $\begin{array}{l}5 \\
(7.5 \%)\end{array}$ & 3.29 & 0.88 \\
\hline $\begin{array}{l}\text { 3.Students concentrate } \\
\text { more on their learning } \\
\text { when using online } \\
\text { applications }\end{array}$ & $\begin{array}{l}3 \\
(4.5 \%)\end{array}$ & $\begin{array}{l}14 \\
(20.9 \%)\end{array}$ & $\begin{array}{l}21 \\
(31.3 \%)\end{array}$ & $\begin{array}{l}22 \\
(32.8 \%)\end{array}$ & $\begin{array}{l}7 \\
(10.4 \%)\end{array}$ & 3.24 & 1.05 \\
\hline $\begin{array}{l}\text { 4.Students try harder in } \\
\text { what they are learning } \\
\text { when using online } \\
\text { applications }\end{array}$ & $\begin{array}{l}2 \\
(3 \%)\end{array}$ & $\begin{array}{l}13 \\
(19.4 \%)\end{array}$ & $\begin{array}{l}25 \\
(37.3 \%)\end{array}$ & $\begin{array}{l}17 \\
(25.4 \%)\end{array}$ & $\begin{array}{l}10 \\
(14.9 \%)\end{array}$ & 3.29 & 1.04 \\
\hline $\begin{array}{l}\text { 5.Students feel more } \\
\text { autonomous in their } \\
\text { learning (they can } \\
\text { repeat exercises if } \\
\text { needed, explore in } \\
\text { more detail topics that } \\
\text { they are interested in, } \\
\text { etc.) }\end{array}$ & $\begin{array}{l}1 \\
(1.5 \%)\end{array}$ & 0 & $\begin{array}{l}13 \\
(19.4 \%)\end{array}$ & $\begin{array}{l}36 \\
(53.7 \%)\end{array}$ & $\begin{array}{l}17 \\
(25.4 \%)\end{array}$ & 4.01 & .77 \\
\hline
\end{tabular}


Vol. 10, No. 4, 2021, E-ISSN: 2226-6348 @ 2021 HRMARS

\begin{tabular}{|c|c|c|c|c|c|c|c|}
\hline $\begin{array}{l}\text { 6.Students understand } \\
\text { more easily what they } \\
\text { learn online }\end{array}$ & $\begin{array}{l}6 \\
(9 \%)\end{array}$ & $\begin{array}{l}10 \\
(14.9 \%)\end{array}$ & $\begin{array}{l}27 \\
(40.3 \%)\end{array}$ & $\begin{array}{l}20 \\
(29.9 \%)\end{array}$ & $\begin{array}{l}4 \\
(6 \%)\end{array}$ & 3.08 & 1.02 \\
\hline $\begin{array}{l}\text { 7.Students remember } \\
\text { more easily what they } \\
\text { have learnt using } \\
\text { online applications }\end{array}$ & $\begin{array}{l}1 \\
(1.5 \%)\end{array}$ & $\begin{array}{l}6 \\
(9 \%)\end{array}$ & $\begin{array}{l}34 \\
(50.7 \%)\end{array}$ & $\begin{array}{l}20 \\
(29.9 \%)\end{array}$ & $\begin{array}{l}6 \\
(9 \%)\end{array}$ & 3.36 & .82 \\
\hline $\begin{array}{l}\text { 8.Students are able to } \\
\text { learn vocabulary better } \\
\text { when it is presented } \\
\text { using online } \\
\text { applications. (Pictures, } \\
\text { Sound, Definition, } \\
\text { Examples, etc.) }\end{array}$ & 0 & $\begin{array}{l}3 \\
(4.5 \%)\end{array}$ & $\begin{array}{l}12 \\
(17.9 \%)\end{array}$ & $\begin{array}{l}38 \\
(56.7 \%)\end{array}$ & $\begin{array}{l}14 \\
(20.9 \%)\end{array}$ & 3.94 & .76 \\
\hline $\begin{array}{l}\text { 9.Students are able to } \\
\text { have a wider range of } \\
\text { vocabulary activities } \\
\text { using } \\
\text { applications. }\end{array}$ & 0 & $\begin{array}{l}2 \\
(3 \%)\end{array}$ & $\begin{array}{l}12 \\
(17.9 \%)\end{array}$ & $\begin{array}{l}40 \\
(59.7 \%)\end{array}$ & $\begin{array}{l}13 \\
(19.4 \%)\end{array}$ & 3.95 & .70 \\
\hline $\begin{array}{l}\text { 10.Using online } \\
\text { applications to test } \\
\text { students' vocabulary } \\
\text { knowledge is more fun } \\
\text { and less stressful. }\end{array}$ & 0 & $\begin{array}{l}1 \\
(1.5 \%)\end{array}$ & $\begin{array}{l}9 \\
(13.4 \%)\end{array}$ & $\begin{array}{l}36 \\
(53.7 \%)\end{array}$ & $\begin{array}{l}21 \\
(31.3 \%)\end{array}$ & 4.14 & .70 \\
\hline $\begin{array}{l}\text { 11.Students can use } \\
\text { the vocabulary learnt } \\
\text { through online } \\
\text { applications better, } \\
\text { providing more visual } \\
\text { examples. }\end{array}$ & 0 & 0 & $\begin{array}{l}14 \\
(20.9 \%)\end{array}$ & $\begin{array}{l}39 \\
(58.2 \%)\end{array}$ & $\begin{array}{l}14 \\
(20.9 \%)\end{array}$ & 4.00 & .65 \\
\hline $\begin{array}{l}\text { 12.Interacting with my } \\
\text { students using online } \\
\text { applications helps } \\
\text { them to remember } \\
\text { their English } \\
\text { vocabulary better. }\end{array}$ & $\begin{array}{l}1 \\
(1.5 \%)\end{array}$ & $\begin{array}{l}2 \\
(3 \%)\end{array}$ & $\begin{array}{l}17 \\
(25.4 \%)\end{array}$ & $\begin{array}{l}37 \\
(55.2 \%)\end{array}$ & $\begin{array}{l}10 \\
(14.9 \%)\end{array}$ & 3.79 & .78 \\
\hline
\end{tabular}

The first 2 items are the teachers' perceptions in using ICT in the teaching and learning general. For the statement "ICT facilitates collaborative work between students", majority of the respondents agree with the statement however there are still respondents who are not 
sure with the statement. 24 respondents are not sure of the statement "ICT improves the online learning (pdpr) (students more engaged, less disturbing)" and another 24 respondents agree with the statement.

Items 3-7 are the teachers' perceptions in using online applications in teaching and learning during online learning. For the statement "students concentrate more on their learning when using online applications" 7 respondents strongly agree with the statement and 3 respondents strongly disagree. Majority of the respondents agree with the statement "students feel more autonomous in their learning (they can repeat exercises if needed, explore in more detail topics that they are interested in, etc.)". Although there are 24 respondents who agree with the statement "students understand more easily what they learn online" , there are 6 respondents who strongly disagree.

Items 8-12 are the teachers' perceptions in using online application in teaching vocabulary during online learning. Based on table 3 , the majority of the respondents agree with the statements however for the statement "interacting with my students using online applications helps them to remember their English vocabulary better" there are 3 respondents who disagree and 17 respondents are not sure whether the interaction using online applications help the students to remember the vocabulary learnt. For item 11, the majority of the respondents agree with the statement "students can use the vocabulary learnt through online applications better, since they provide them with more visual examples" and none disagree but there are 14 respondents who feel unsure with the statement.

\section{Discussion and Conclusion}

This study is more related in identifying the types of online applications teachers use when teaching vocabulary during online learning. Furthermore, it examines the perceptions of teachers in incorporating online applications in the teaching and learning of vocabulary during online learning. Based on the study, the findings indicate that WhatsApp and Telegram are the two frequently used online applications in teaching vocabulary by teachers. The online applications that are least frequently used by teachers in teaching vocabulary are Google Meet and Quizwhizzer. The findings also highlight that there are mixed perceptions among the teachers when it comes to using online applications in teaching vocabulary.

This study will offer priceless information to the school administration as well as to educational policy makers regarding the nature of online application integration to the teaching-learning process. Since the attitude and perceptions of the teachers are critical to how effectively online application is incorporated, it is important to gauge how teachers perceive this strategy and its efficacy of online applications as a tool for enhancing the teaching and learning of vocabulary during online learning.

In future studies more focus should be given on the rationale of teachers using only the selected online applications and exploring the challenges and barriers of using the online applications in teaching vocabulary. 


\section{Acknowledgement}

The authors would like to give special thanks to the Ministry of Education Malaysia through the sponsorship given.

\section{References}

Adnyani, K. E. K., Adnyana, I. W., \& Murniasih, N. N. (2020). Teacher and Students' Perception on Using Kahoot! for English Learning. 3rd International Conference on Innovative Research Across Disciplines (ICIRAD 2019) 62-67). Atlantis Press. https://doi.org/10.2991/assehr.k.200115.011

Alfehaid, A. (2019). Online English Language Learning Activities and Academic Achievement: Experiences of First Year Students and Their Teachers. Pertanika Journal Social Sciences \& Humanities, 27 (3), $1557-1572$.

http://www.pertanika.upm.edu.my/pjssh/browse/regular-issue?article=JSSH-49942019

Bates, A. W. (2005). Technology, E-learning and Distance Education. New York: Routledge.

Boticki, I., Baksa, J., Seow, P., \& Looi, C. K. (2015). Usage of a mobile social learning platform with virtual badges in a primary school. Computers \& Education (86), 120-136

Çetin, H. S. (2018). Implementation of the digital assessment tool kahoot in elementary school. International Technology and Education Journal, 2(1), 9-20

Chen, M. H., Tseng, W. T., \& Hsiao, T. Y. (2018). The effectiveness of digital game-based vocabulary learning: A framework-based view of meta-analysis. British Journal of Educational Technology, 49(1), 69-77. https://doi.org/10.1111/bjet.12526

Coates, H., We, Shi, W. J. H. (2020). Crisis is making online education economy go mainstream. University World News: The Global window on higher education. https://www.universityworldnews.com/post.php?story=20200302091409436.

Domingo, M. G., \& Garaganté, A. B. (2016). Exploring the use of educational technology in primary education: Teachers' perception of mobile technology learning impacts and applications' use in the classroom. Computers in Human Behavior (56), 21-28

Earslan, A., \& Topkaya, E. Z. (2017). EFL students' attitudes towards e-learning and effect of an online course on students' success in English. The Literacy Trek, 3(2), 80-101.

Famularsih, S. (2020). Students' Experiences in Using Online Learning Applications Due to COVID-19 in English Classroom. Studies in Learning and Teaching, 1(2), 112-121. https://doi.org/10.46627/silet.v1i2.40

Ghavifekr, S., Kunjappan, T., Ramasamy, L., \& Anthony, A. (2014). Teaching and learning with ICT tools: issues and challenges from teacher's perceptions. Malaysia Online Journal of Educational Technology, 4(2), 38-57

Gorjian, B., Moosavinia, S. R., Kavari, K. E., Asgari, P., \& Hydarei, A. (2011). The impact of asynchronous computer-assisted language learning approaches on English as a foreign language high and low achievers' vocabulary retention and recall. Computer Assisted Language Learning, 24(5), 383-391. https://doi.org/10.1080/09588221.2011.552186

Hashim, H., Md. Yunus, M., Embi, A. M., \& Ozir, M. N. A. (2017). Mobile-assisted Language Learning (MALL) for ESL Learners: A Review of Affordances and Constraints. Sains Humanika, 9(1-5), 45-50. https://doi.org/10.11113/sh.v9n1-5.1175

Huei, L. S., Yunus, M., \& Hashim, H. (2021). Strategy to Improve English Vocabulary Achievement during Covid-19 Epidemic. Does Quizizz Help?. Journal of Education and e-Learning Research, 8(2), 135-142. 
https://doi.org/10.20448/journal.509.2021.82.135.142.

Kumar, R. (2019). Research Methodology: A Step-by-Step Guide for Beginners (5th ed.). SAGE Publications Ltd.

Lakshmi, G. V. S. A. (2016). Mobile apps: A powerful tool for vocabulary development. International Journal of English: Literature, Language and Skills, 5(2), 142-148

Lin, J. J., \& Lin, H. (2019). Mobile-assisted ESL/EFL vocabulary learning: A systematic review and meta-analysis. Computer Assisted Language Learning, 32(8), 878-919. https://doi.org/10.1080/09588221.2018.1541359

Ministry of Education Malaysia. (2015). English language education reform in Malaysia: The Roadmap 2015-2025. English Language Standards and Quality Council.

Nguyen, T. T. T., \& Yukawa, T. (2019). Kahoot with smartphones in testing and assessment of language teaching and learning, the need of training on mobile devices for Vietnamese teachers and students. International Journal of Information and Education Technology, 9(4), 286-296. https://doi.org/10.18178/ijiet.2019.9.4.1214

Ningsih, S., \& Mulyono, H. (2019). Digital Assessment Resources in Primary and Secondary School Classrooms: Teachers' Use and Perceptions. https://doi.org/10.3991/ijim.v13i0

Purwanto, A., Pramono, R., Asbari, M., Hyun, C. C., Wijayanti, L. M., Putri, R. S., \& Santoso, P. B. (2020). Studi eksploratif dampak pandemi COVID-19 terhadap proses pembelajaran online di sekolah dasar. EduPsyCouns: Journal of Education, Psychology and Counseling, 2(1), 1-12.

Rezaei, A., Mai, N., \& Pesaranghader, A. (2014). The effects of mobile applications in English vocabulary acquisition. Jurnal Teknologi,68 (2), 73-83 https://doi.org/10.11113/jt.v68.2912

UNESCO. (2020). Global Education Meeting: Extraordinary Session on Education post-Covid 19.1-24.https://doi.org/https://en.unesco.org/sites/default/files/gem2020extraordinary-session-background-document-en.pdf

Yang, X., Li, X., \& Lu, T. (2015). Using mobile phones in college classroom settings: effects of presentation mode and interest on concentration and achievement. Computers \& Education, 88, 292-302. 